Rompres. 1993. "Non-Recognition of Benarnbian Church Appeiled." Bucharest. March 15.

Rossiyskaya Gazeta. 1993. "Intelligentain Congress Opts for Unification with Romania." January 27.

Rozenberg, Lev. 1993. "Conference at Dniester University Takes on Anti-Semitic Overtones." In Monitor 4, October 1992-February 1993.

Selivanov, Yury. 1993. "Gagauzia Reaches the Limit." In Megapolis-Express, April 7.

Sheehy, Ann. 1993. "Moldova's National Income Drops Further." In Radio Free Europe 138, July 22.

Socor, Vladimir. 1993. "CSCE's Moldova Mission Shows Meager Results." In Radio Free Europe, November 10.

- 1993. "Russia Sees Moldova as Object of Great Game." In Radio Free Europe, November 8 .

_. 1993. "Moldova Damaged by Russian Economic Pressure." In Radio Free Europe, November 5.

1993. "Tension on the Dniester Rising." In Radio Free Europe 212, November 4.

- 1993. "Israel Pleased with Situation of Moldova's Jews." In Radio Free Europe, October 22.

_. 1993. "Russia Rebuffs Moldovan Foreign Minister." In Radio Free Europe 202, October 20 , a.

- 1993. "Russian Economic Support to Dniester Republic." In Radio Free Europe 202, October 20, b.

- 1993. "Yeltsin Snubs Snegur." In Radio Free Europe 202, October 20, c.

- 1993. "Death Penalty Demanded in Tiraspol Trial." In Radio Free Europe 196, October 12.

- 1993. In Radio Free Europe, September 23. 1993. "Lebed Wins Again." In Radio Free Europe 176, September 14.

. 1993. "Moldovan Protest to Russia." In Radio Free Europe, September 13.

_. 1993. "Moldova's 'Dniester' Ulcer." In Radio Free Europe/Radio Liberty Research Report, 2(1):15, January 1.

Soldatova, G. 1993. "Respublika Moldova (The Moldova Republic)." e-mail connection, April 7.

Zarya Pridnestroviya. 1992. "Na poslednem beregu. Kto otvetit za krovavii etnograficheskii terror $v$ Moldove? (On the last bank. Who will be responsible for the bloody ethnic terror in Moldova?)." June 20. •

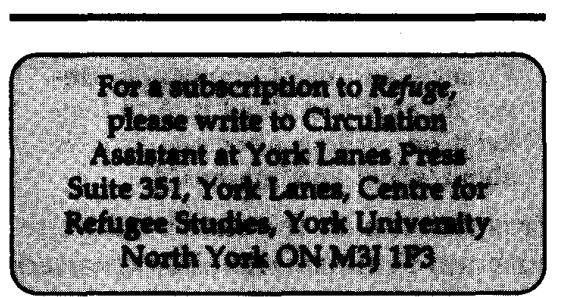

\title{
Anti-Semitism and Its Effect on Emigration Potential of Ukrainian Jews
}

\author{
Alexander Benifand and Tanya Basok
}

Several Western analysts have argued that Jews are no longer interested in emigrating from Ukraine because the era of state policy of anti-Semitism is over and now Ukrainian Jews can engage freely in reviving their culture. However, it appears that this view is too optimistic. In reality, the significant reduction in state anti-Semitism has been more than compensated by grassroots anti-Semitic incidents which the state at the present time is unable and unwilling to curb.

The Jewish community is experiencing serious difficulties in trying to revive its culture. As a result, most Jews continue considering emigration. For many residence in Western countries has become nothing more than a dream because of the difficulties in obtaining visas to go there. At the same time, hardship experienced by recent arrivals to Israel and the persisting political instability there have lowered the interest of selecting aliah as a viable alternative. While some have chosen Israel as their new home, many are still waiting to see if the situation in this country will improve before they emigrate.

Anti-Semitism in the Ukraine has roots that are several centuries old. Ukrainian Jews are well acquainted with bloody pogroms and persecution. Ukraine President Leonid Kravchuk attributes anti-Semitism in the Ukraine to Russian and Soviet policies of divide-and-rule. Whether or not it was a deliberate policy of Moscow, in many respects, Ukrainian anti-Semitism is now stronger than in Russia.

Prior to Gorbachev's reforms, the Ukraine state's anti-Semitic policy was more thorough than Russia's (Chertok 1993). However, in Ukraine, as in many other Eastern European countries, ex-Communists have "reformed themselves," into nationalists
(Kovrigin 1993). Grassroots antiSemitism has penetrated all spheres of life and is unlikely to disappear for some time. According to Sheldon Kirshner,

State anti-Semitism has vanished since the advent of Ukrainian independence, yet grassroots antiSemitism is far from dead (Kirshner 1993).

In his recent testimony to the Human Rights Committee of the House of Representatives of the US Congress, Semyon Gluzman, Director of the Ukrainian Bureau on Human Rights, noted that according to a recent survey:

18 percent of Ukrainians blame Jews
for the catastrophe caused by the
1917 Revolution; 38 percent believe
that, for Jews, money and profit are
much more important than human
relations; and 10 percent consider
Jews responsible for the present ills
suffered by other people
(Informatzionnii Bulleten AARE 1993).

Given these opinions, it is hardly surprising that anti-Semitic incidents are occurring. In December 1992, the Ukrainian National Party held a demonstration outside the Odessa Television Centre protesting the large number of Jews employed in the TV industry (Dobrivker 1993). On March 21, 1993, a group of young men burst into the Lviv City Centre for Jewish Culture, shouting anti-Semitic slogans and threatening to use violence (Arolovich 1993). After Dmitry Dvorkis, of Jewish origin, was elected mayor of Vinnitsa, a protest was organized by the Ukrainian National Assembly during which anti-Semitic slogans were sung (Khazan 1993).

Examples of anti-Semitic vandalism abound. On the night of November 10, 1992, a plaque of Jewish writer, Sholom-Aleikhem, was splashed with

Refuge, Vol. 13, No. 7 (November-December 1993) 
paint (Yatsyuk 1992, November 12). On November 21, 1992, a sculpture to the memory of the victims of Babi-Yar received the same fate (Kievskie Vedomosti 1992).

In Kiev, unknown assailants placed explosives in the city's oldest functioning synagogue and posters of the Lubavitcher rebbe were defaced. In Kharkov, a severed pig's head was dumped in front of the city's only synagogue. In Dnepropetrosk, a swastika was scrawled on a wall of the synagogue (Kirshner 1993).

Anti-Semitic newspapers are sold freely, and anti-Semitic posters are virtually unopposed in Kiev (Evreiskie Vesti 1992). The newspaper, Nova Ukraina, published an article accusing Constantinople Jews of conspiring with Spanish Jews to take over Spain (Antonov 1992). Another newspaper, Za Vilnu Ukrainu, published by the Ukrainian Nationalist Assembly, printed an article by Pavel Chemeris, in which he put the blame for the "Socialist experiment" on Jews (Mirsky 1993).

The political atmosphere for Jews in the Ukraine became particularly tense during the trial of Ivan Demyanyuk in Israel, on the suspicion that he worked in a Nazi camp as a guard. Nationalists promised that if he was convicted, there would be reprisals against Jews in the Ukraine (Milner 1993). The examples of Western countries show that grassroots racism usually persists long after official declarations of anti-racist policies. In those countries where antiracist hate literature is not illegal, human rights legislation does not exist, and commissions or boards in charge of hearing and adjudicating charges of racism are absent, one cannot expect racist acts to vanish; this, unfortunately, is the case in the Ukraine. The activities of ultra-right organizations are not prosecuted, and no one initiates investigations into the origin of anti-Semitic flyers (Schedrina 1992).

There are also numerous examples of vandalism which go unpunished. In Evpatoria, for instance, a group of people vandalized a plaque commemorating a massacre of Jews which took place on November 24, 1941. One of those who drew a swastika and wrote anti-Semitic graffiti on the plaque was caught, yet the District Attorney ordered him released (Lyustin 1992; Sholom 1992). As a result of such amnesties, neo-Nazi organizations such as the "Legion of New Order" and "Skhidnii Khrest" are becoming more openly anti-Semitic. On October 24, 1992, 40 members of these organizations publicly burned Jewish newspapers and the Star of David. The participants promised that in the future, such acts would be more frequent (Yatsyuk 1992, November 5).

It seems that as long as no one is lynched, these and other openly illegal acts of ethnic hatred are perceived as "political pluralism" (Kapelyushnii 1992). Even when acts of violence against people are committed, the police remain unmoved. In one instance, an apartment of a Jewish writer was set on fire and anti-Semitic graffiti written on the wall. Only several days later did the police arrive to take evidence. The graffiti included as evidence only at the insistence of one of the victims (Sneider 1992; Arkadyev 1992). Police brought no action in another reported incident in which a Jewish man was beaten by two Russians (Monitor 1993).

Some critics trace the inability and unwillingness to protect the rights of Jews to the Ukraine government itself. According to Simon Wiesenthal, head of the Jewish Documentation Centre in Vienna, Ukrainian authorities are renaming streets after former pogromists, such as Simon Petlura. Wiesenthal sent a letter to President Kravchuk, reminding him that Petlura's fighters killed 80,000 Jews in 1918-20. ${ }^{1}$ The President replied through the Austrian Embassy, explaining that renaming streets is a prerogative of local government bodies, not the central government (Kovrigin 1993, 16,17). That did not appease Wiesenthal however, and when the Ukrainian Deputy Prime Minister invited him to a memorial for the victims of Babi-Yar, he declined, explaining:

[The] Germans who invaded an alien territory didn't know how to find
Jews and Communists. They would have been unable to kill so many people if not for the help rendered them by local hangmen. This must not be forgotten. This is precisely why I declined the invitation. I can't afford taking part in falsifying history. Today they don't want to remember about the collaboration of the Ukrainian police with fascists. Such people can't be rehabilitated (ibid.).

There have also been examples of antiSemitic statements made by People's Deputies. Shkuratiuk, for instance, stated publicly at a session of the regional Soviet in Rovno on December 14,1992 , that he was proud that "Ukrainians took part in the execution of Jews in Babi-Yar." He accused Jews of being active in the security agencies which persecuted Ukrainians in the 1930s (Arolovich 1993). In February 1993, the paper Golos Ukraini (Voice of Ukraine) published an article by Kalinets, People's Deputy, in which he accused Jews of "constant complaining of bad treatment by Ukrainians during World War II," which, according to the author, "was not true" (Milner 1993).

According to Gregory Marianovsky, Chair of the Human Rights Commission of the Kharkov City Council, the state does not officially support anti-Semitism. However, there are anti-Semitic groups, even in Rukh. ${ }^{2}$ An openly anti-Semitic and militant nationalist organization, Ukrainskaya Samooborona (Ukrainian Defence), enjoys the support of the Head of Regional Militia. There is provision in the Criminal Code against the incitement of ethnic hatred, but the Attorney General, citing freedom of the press did not invoke this provision even for such openly anti-Semitic newspapers as Novaya Ukraina, which clearly incite ethnic hatred. Marianovsky concluded that:

Today, [Ukrainian authorities] are inciting hatred even in the City Council, and our Commission cannot do anything about it. And they keep on writing atrocious articles about 'kikes' and 'masons.'

Frustration over the state's failure to curb anti-Semitism was also expressed 
by Semyon Gluzman in his testimony to the U.S. Congress:

In cases of barbaric anti-Semitic actions, as a rule, special services (Militia) of the Ukraine cannot (or do not want) to find those who are guilty (Arolovich 1993).

Some analysts have argued that the Jewish community is experiencing a revival in the Ukraine, but this seems overly optimistic. Jewish culture in the Ukraine is virtually dead. There is no Jewish community with its own language, traditions, religion and schools. There are only a few synagogues and no indigenous rabbis. In the last few years, Jewish organizations, synagogues and schools have received official titles to some buildings, but the high costs of their maintenance has made it extremely difficult to keep them (ibid.; Kirshner 1993). A Jewish doctor from Donetsk writes:

In spite of some revival of Jewish life, the situation in the city is complicated and even dangerous. The growing anti-Semitism among the population and the full negligence on the part of the authorities really scares us. We are constantly in fear. We have been directly threatened on many occasions because of our activism in the Jewish community (Monitor 1993).

The Department of Demography of the Jerusalem University estimates that there are 350,000 Jews in the Ukraine today, less than one-third of the Jewish population in 1926. Even in 1979 , there were still 634,154 Jews, and in 1989 , they numbered 487,307 . Ninety percent of Jews residing in the Ukraine consider Russian their native tongue, and the remaining ten percent are elderly people (Arolovich 1993). Rather than a revival of Jewish culture, the collapse of Communist rule has led to a revival of anti-Semitism. Unfortunately, the present economic and political uncertainty in the Ukraine is likely to contribute to this revival. Persistent anti-Semitism, alienation from the Ukrainian culture, and failure of the Jewish community to rebuild itself would likely to encourage many Ukrainian Jews to consider emigration as an alternative.

\section{Notes}

1. In 1926, Petlura was shot by a young Ukrain ian Jew in Paris. Petlura's assassin was acquitted when it was discovered that 15 members of his family had fallen victim to Petlura's pogroms. When Germans occupied Lviv in 1941, they gave complete freedom to Ukrainian nationalists who then killed 8,000 Jews in a matter of a days.

2. There was a recent attempt to separate Rukh Kharkov from the All-Union Rukh under the motto "All Non-Ukrainians Must Leave." The situation in Kharkov Rukh has since stabilized and those holding anti-Semitic views have been expelled (Gluzman).

3. Gregory Marianovsky, telephone interview, March 10, 1993.

\section{References}

Antonov, G. 1992. "Chem Pakhnet (What Does it Smell of)?" In Khadashot Novosti 4(8).

Arkadyev, David. 1992. "Vesna Trevogi Nashei (The Spring of Troubles)." In Vozrozhdenie 4, April.

Arolovich, Inna, 1993. "Ukraine Grows Hostile Toward Jews." May 20, unpublished paper.

Canadian Jewish News. 1993. "Jewish Agency Getting Ready for Ukrainian Jewish Influx." November 4.

Chertok, Shimon. 1993. "Na Ukraine Ne Budet Anti-Semitisma - There Will Be No AntiSemitism in Ukraine." In Novoe Russkoe Slovo, January 29.

Dobrivker, Boris. 1993. “Nationalists Protest Jewish Control of Television." In Monitor 4 October 1992-February 1993.

Evreiskie Vest. 1992. 10(6), September.

Gluzman, Semyon. "Anti-Semitism in Ukraine." Union of Council for Soviet Jews (Washington, D.C.) unpublished document, no date.

Informatzionnii Bulleten AARE. 1993. (A newsletter published by the American Association of Russian Jews, New York), May 20.

Kapelyushnii, Leonid. 1992. "Perunovo Proklyatie slishitsya segodnya $v$ nashikh natsional'nikh mezhdoysobitsakh (Perun's Damnation is Heard Today in our Ethnic Conflicts)." In Izvestiya February 17.

Khazan, Liubov. 1993. "Vinnitsa Elects Jewish Mayor, 'National Patriots' React." In Monitor 4, October 1992-February 1993.

Kieoskie Vedomosti. 1992. "Nad Babim Yarom Varvari Glumyatsya (Barbarians Are Making Fun of Babi Yar)." November 24.

Kirshner, Sheldon. 1993. "Sadness pervades Odessa." In The Canadian Jewish News, January 7.

Kovrigin, Anatoly, 1993. "Now They Name Streets After Petlura." In The New Times 14.

Lyustin, V.N. 1992. "Son Razuma Porozhdaet Chudovisch (Dreams Create Monsters)." In Sholom (Simferopol) 10(27), October.
Milner, Mila 1993. "Ukraine Chauvinism Forum Postponed." In Monitor 4, October 1992-February 1993.

Milner, Peter. 1993. "Ukraine Growing Hostile Toward Jews." In Monitor 4, October 1992 February.

Mirsky, Rudloph. 1993. "Jews Blamed for 'Socialist Experiment'." In Monitor 4, October 1992-February 1993.

Monitor. 1993. "Jewish Man Beaten, Militia Refuse to Respond." October 1992-February 1993.

___ 1993. "A Letter from Donetsk on Jewish Life." October 1992-February 1993.

Schedrina, Olga. 1992. "Suschestvuet li 'evreiskii vopros' na Ukraine (Is There a 'Jewish Question' in Ukraine)?" In Literaturnaya Gazeta, November 4.

Sholom. 1992. "Nakazat oskvernitelei pamyatnikov (Should Those Who Desecrate Graves be Punished)?" (Simferopol) 10(27), October.

Sneider, Daniel. 1992, "Confronting the Resurgence of Anti-Semitism." In The Christian Science Monitor, April 1.

Yatsyuk, Dmitri. 1992. "Ocherednaya Vilezka Fashistov. Postradal Sholom-Alekhem (Another Act by Fascists. Sholom-Aleikhem is Victimized)." In Kieuskie Vedomosti, November 12.

—_ 1992. "Zauryadnii Fashism: Kostyor Nenavisti (Ordinary Fascism: Fire of Hatred)." In Khadashot (Kiev) 7(11).

—_ 1992. "Oni Zayavlyayut of Sebe, 'Mi Ukrainskie Fashisti. Cherez Neskol'ko Let Kiev Stanet Vtorim Myunkhenom...' (They Claim, 'We are Ukrainian Fascists'. In a Few Years Kiev Will be Second Munich)." In Kievskie Vedomosti 48(54), November 5.

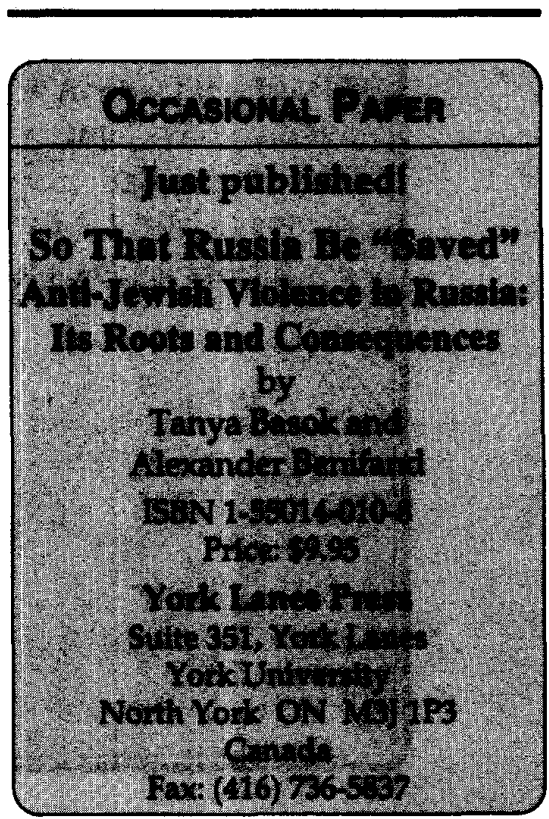




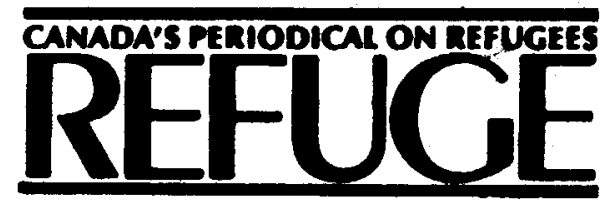

Refuge

York Lanes Prees

Centre for Refugee Studies

Suite 351, York Lanes, York Univervity $\$ 700$ Keele Street, North York

Ontario, Canada M3J 1P3

Phone: (416) 736-5843 - Fax: (416) 736-5837

Electronic Mall vin Bitnet Addres:

REFUGEQVM1.YORKU.CA

Postage Paid in Toronto, Canada

Second Class Mail Registration No. 5512

Return Postage Guaranteed

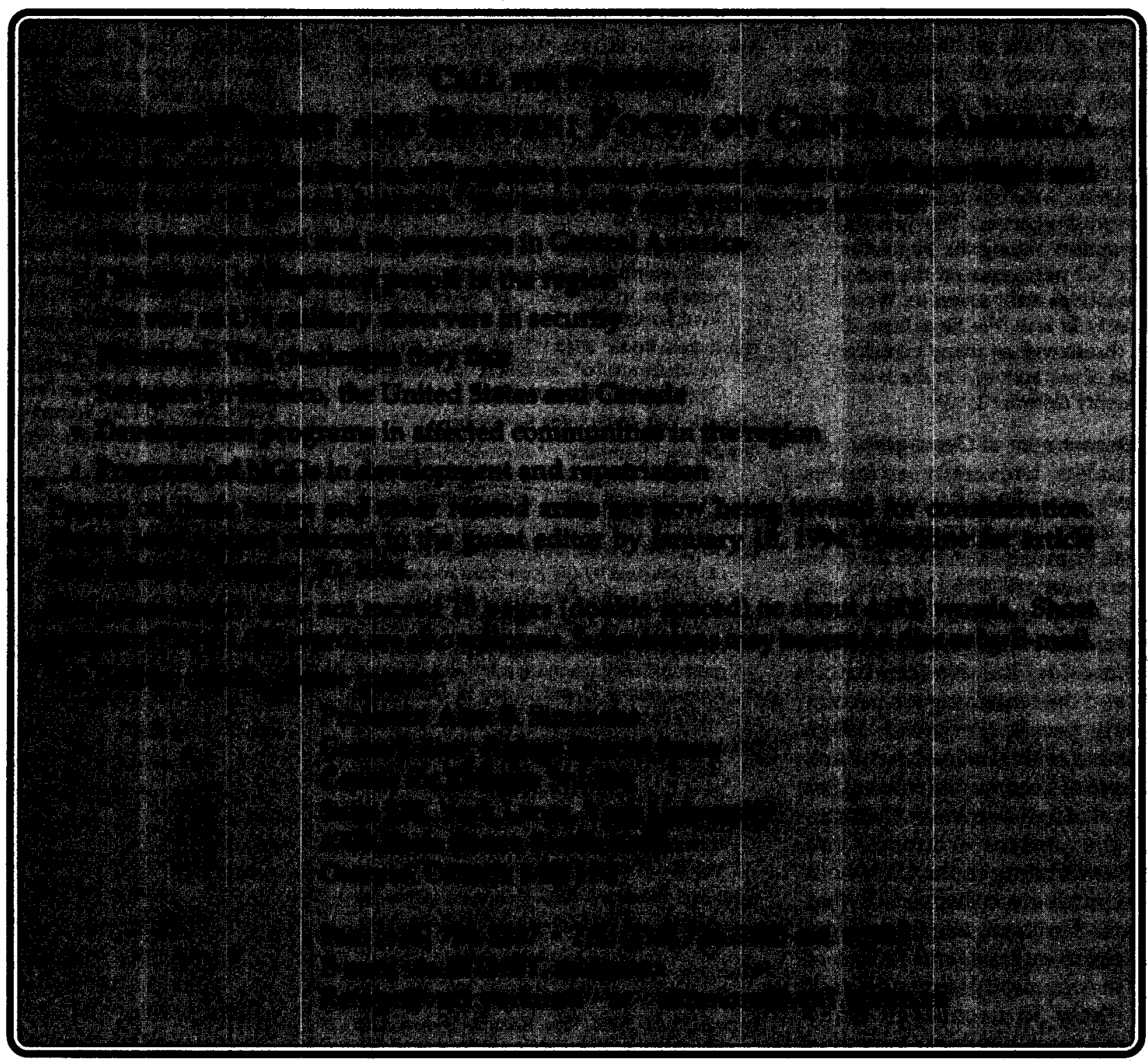

(C) Tanya Basok and Alexander Benifand, 1993. This open-access work is licensed under a Creative Commons Attribution-NonCommercial 4.0 International License, which permits use, reproduction and distribution in any medium for non-commercial purposes, provided the original author(s) are credited and the original publication in Refuge: Canada's Journal on Refugees is cited. 